We thank Dr Salvatore Caredda of the Istituto di Agronomia e Coltivazioni Erbacee, University of Sassari, for his help with the statistical analysis, and to Farmitalia, Milan, for the generous supply of metergoline.

Requests for reprints should be addressed to Dr G Delitala, Cattedra di Semeiotica Medica 2a, Università di Sassari, Viale S Pietro 12, 07100 Sassari, Italy.

\section{References}

${ }^{1}$ Jeffcoate, T N A, et al, British Medical fournal, 1968, 4, 19.

2 Varga, L, et al, Schweizerische medizinische Wochenschrift, 1972, 102, 128.

${ }^{3}$ Fluckiger, E, and Wagner, H R, Experientia, 1968, 24, 1130

4 Lutterbeck, P M, et al, British Medical fournal, 1971, 3, 228.

5 Pasteels, J L, et al, Annales d'Endocrinologie, 1972, 32, 188.

6 Corrodi, H, et al, Fournal of Pharmacy and Pharmacology, 1973, 25, 409.

${ }^{7}$ Kamberi, I A, Mical, R S, and Porter, J C, Endocrinology, 1971, 88, 1288
${ }^{8}$ Lu, K H, Meites, J, Endocrinology, 1973, 93, 152.

${ }^{9} \mathrm{Kato}, \mathrm{Y}$, et al, Fournal of Clinical Endocrinology and Metabolism, 1974, 38, 695.

${ }^{10}$. Beretta, C, Ferrini, R, and Glasser, A H, Nature, 1965, 207, 421.

11 Chiodini, G P, et al, fournal of Clinical Endocrinology and Metabolism, $1976,43,356$.

12 Delitala, G, et al, fournal of Clinical Endocrinology and Metabolism, 1976, 43, 1382.

13 Pontiroli, A E, et al. In press.

14 Delitala, G, et al, Biomedicine. In press.

15 Del Pozo, E, Brun, del Re R, and Hinselman, American fournal of Obstetrics and Gynecology, 1975, 123, 845.

${ }^{16} \mathrm{McNeilly,} \mathrm{A} \mathrm{S,} \mathrm{Proceedings} \mathrm{of} \mathrm{the} \mathrm{Royal} \mathrm{Society} \mathrm{of} \mathrm{Medicine,} \mathrm{1973,} \mathrm{66,} 863$.

17 Delitala, G, et al, Studi Sassaresi, 1976, 54, 3.

18 Shaar, C J, and Clemens, J A, Endocrinology, 1974, 95, 1202.

19 Ferrini, R, and Glässer, A H, Psychopharmacologica, 1965, 8, 271.

${ }^{20}$ Füxe, K, Agnati, L, and Everitt, B, Neuroscience Letters, 1975, 1, 283.

${ }^{21}$ Delitala, G, et al, fournal of Clinical Endocrinology and Metabolism. In press.

\title{
Unsuspected exposure to asbestos and bronchogenic carcinoma
}

\author{
K M MARTISCHNIG，D J NEWELL，W C BARNSLEY，W K COWAN, E L FEINMANN, E OLIVER
}

British Medical fournal, 1977, 1, 746-749

\begin{abstract}
Summary
Two hundred and fifty men admitted to a thoracic surgical centre and matched controls were questioned in detail about their occupations after leaving school and their smoking habits. Of 201 men with confirmed bronchial carcinoma 58 gave a history of occupational exposure to asbestos, whereas only 29 out of 201 men matched for age and residential area who were admitted with other diseases gave such a history. This difference was statistically highly significant. The usual association of bronchial carcinoma with heavy smoking was observed, but asbestos exposure increased the risk of carcinoma whatever the level of smoking. These results are consistent with the hypothesis that asbestos exposure and the level of smoking act independently in causing bronchial carcinoma. The patients with carcinoma who had been exposed to asbestos presented on average three years earlier than those who had not been exposed. Asbestos regulations have eliminated the risk of exposure to workers in scheduled industries, so asbestos-induced diseases will probably be increasingly found among the many workers who have had incidental exposure to asbestos. It is therefore important to take a full occupational history.
\end{abstract}

Queen Elizabeth Hospital, Gateshead, Tyne and Wear NE9 6SX

K M MARTISCHNIG, MD, chest physician

W K COWAN, MD, pathologist

E L FEINMANN, FRCP, chest physician

E OLIVER, FIMLS, chief technician

Department of Medical Statistics, University of Newcastle upon Tyne, Newcastle upon Tyne NE2 4AA

D J NEWELL, MA, PHD, professor

Shotley Bridge General Hospital, Consett, Co Durham DH8 0NB W C BARNSLEY, FRCS, thoracic surgeon

\section{Introduction}

The association between exposure to asbestos dust and bronchial carcinoma was first reported in $1935 . .^{1}$ In this report, as in many others over the next three decades, the incidence of carcinoma was investigated in people with asbestosis. This implied that asbestosis - that is, fibrosis-was a factor in the carcinogenesis. This view survives today in the United Kingdom, where a person with bronchial carcinoma who has been exposed to asbestos is entitled to compensation only if asbestosis is present.

But if asbestos is a carcinogen it may operate in the absence of asbestosis, and in the last two decades the problem has been approached more broadly through the study of groups of asbestos workers who may or may not have asbestosis. ${ }^{23}$ Exposure to asbestos can, however, also occur in people who are not ostensibly "asbestos workers," as careful history taking can establish. Over the years one of us (WCB) has noied that many patients with bronchial carcinoma have had such exposure, which has not been associated with the occupation given on routine records.

This study was planned to determine whether "unsuspected" exposure in the absence of asbestosis does predispose to carcinoma, whether smoking is relevant in this context, and whether this "asbestos cancer" differs in any way from other bronchial carcinomas.

\section{Patients and methods}

\section{OCCUPATIONAL HISTORY}

Men admitted to a thoracic surgical centre during the course of one year (April 1972-March 1973) for investigation of possible lung cancer were interviewed by one of us (KMM). A meticulous history was obtained of every type of work they had done since leaving school, directed initially to the duration and broad type of occupation. Specific details were then sought without the interviewer mentioning asbestos, and at this stage a history of asbestos exposure was sometimes obtained. The following examples illustrate exposure occurring in occupations not ostensibly connected with asbestos and disclosed at the interview.

Case 1-A 61-year-old naval engineer had repaired burst pipes (two or three a week) and relagged them in confined spaces in ships. He had done this job for 15 years. 
Case 2-A 63-year-old railway worker had worked as a plumber's mate in the shipyards for 13 years. He had used asbestos plungers in areas without ventilation.

Case 3-A 72-year-old foreman corker had worked inside ships with laggers for 20 years. He had had to work in very dusty conditions.

Case 4-A 76-year-old Post Office worker had worked in a boiler shop for two years. He used to knock out bricks and sweep up asbestos debris.

Case 5-A 67-year-old miner had worked on buildings with asbestos and plaster in sheds for nine years. He used to open the packs of asbestos.

Case 6-A 56-year-old building shop manager used to work as a storeman, handling all types of asbestos, wet and dry. He had done this for 27 years.

Case 7-A 59-year-old clerk had once worked for eight years as a welder's mate on old ships. The laggers removed the lagging and he put the debris into buckets and sacks.

Case 8-A 55-year-old tailor's cutting-room manager worked in a small room where there were at least 12 asbestos pads to stand irons on. These pads had to be replaced every three to four months.

Case 9-A 57-year-old labourer worked in an electrical factory where motors were tested wrapped in asbestos sheets to keep heat in. After testing the sheets were removed and he swept the floors, putting dust into sacks.

Case 10-A 54-year-old labourer in a paint factory crushed asbestos and mixed it with paints in cannisters. Although he was supplied with a mask he did not wear it regularly. He had done this job for eight years.

Out of 250 men interviewed 201 were subsequently found to have lung cancer, a firm diagnosis being made by radiography, bronchoscopy, or thoracotomy. None had asbestosis and none had ever worked in asbestos manufacturing industries or used asbestos as a principal material in their work. When a history of asbestos exposure was obtained the duration was recorded (1-5 years and 6 years and over) It was not practical to estimate the degree of exposure in terms other than its duration.

\section{SMOKING HISTORY}

The patients were classified according to the greatest number of cigarettes they had ever smoked regularly.

\section{PULMONARY FUNCTION}

Ventilatory measurements by Vitalograph and peak flow meters were made on all patients. In many of those who were considered for surgery single blood transfer factor was measured and blood gas analysis and maximal and submaximal exercise studies were performed. (LF).

\section{CONTROLS}

Patients in general hospitals with the same catchment area as the thoracic surgical unit who had no evidence of bronchial carcinoma acted as controls. For each of the 250 men a male control, matched for age within two years, was interviewed in exactly the same manner, and from this group 201 matched controls were taken.

\section{ASBESTOS FIBRE COUNTS}

Resected lung specimens from several patients with bronchial carcinoma were examined for asbestos fibres by an investigator who had no knowledge of the occupational history.

A piece of tissue, approximately $2 \times 1 \times 1 \mathrm{~cm}$, was taken and divided into two blocks of the same texture and size. Both blocks were weighed and the weights recorded. One block was dried at $70^{\circ} \mathrm{C}$ to a constant weight and this weight of dried lung tissue was again recorded. From this the weight of dried lung tissue in the other block was calculated. The wet block of tissue was macerated in $6 \mathrm{ml}$ of $40 \%$ potassium hydroxide at $100^{\circ} \mathrm{C}$ and the volume then made up to $10 \mathrm{ml}$ with distilled water. The tubes were centrifuged at $3000 \mathrm{rpm}$ for 15 minutes, and the supernatant fluid was poured off. The deposit was resuspended in $10 \mathrm{ml}$ of distilled water.

The suspension was well mixed, placed in Fuchs-Rosenthal counting chambers, and allowed to settle for 10 minutes. Fibres in an area of $100 \mathrm{~mm}^{2}$ with a depth of $0.2 \mathrm{~mm}$ were counted under phase-contrast microscopy. Counts were expressed as numbers of fibres per gram of dried lung tissue.

\section{Results}

Of the 201 men with cancer $58(29 \%)$ gave a history of exposure to asbestos, compared with only $29(14 \%)$ of the 201 controls. Even without allowing for individual matching of cases and controls, this result was highly significant $\left(\chi^{2}=12.3 ; P<0.001\right)$. The patients with carcinoma were more likely to have had a longer exposure: 37 of the patients but only 12 of the controls had been exposed for over five years $\left(\chi^{2}=3.95 ; \mathrm{DF}=1 . \mathrm{P}<0.05\right)$.

The well known relation between smoking and bronchial carcinoma was seen again in this study (table I). A smoker who smoked 25 or more cigarettes a day had a risk of having carcinoma over nine times that of a non-smoker. As in previous retrospective studies (see, for example, the report of the Royal College of Physicians ${ }^{4}$ for a summary of more than 30 such investigations), the association was direct-that is, the risk of bronchial carcinoma increased for each successive level of cigarette smoking. A formal statistical test confirmed this observation. The proportion of patients with cancer who fell into the various smoking groups increased linearly with the amount of smoking, and there was no evidence that the risk either reached a plateau at some level of smoking or increased exponentially with the amount smoked.

TABLE I-Smoking and bronchial carcinoma

\begin{tabular}{|c|c|c|c|c|c|}
\hline & \multicolumn{5}{|c|}{ Greatest number of cigarettes smoked daily } \\
\hline & 0 & $1-14$ & $15-24$ & 25 & Total \\
\hline $\begin{array}{l}\text { Patients with cancer } \\
\text { Controls } \quad \ldots \quad \ldots\end{array}$ & $\begin{array}{r}4 \\
25\end{array}$ & $\begin{array}{l}31 \\
39\end{array}$ & $\begin{array}{l}91 \\
87\end{array}$ & $\begin{array}{l}75 \\
50\end{array}$ & $\begin{array}{l}201 \\
201\end{array}$ \\
\hline Relative risks & 1 & $5 \cdot 0$ & $6 \cdot 5$ & $9 \cdot 4$ & \\
\hline
\end{tabular}

$\chi^{2}=18.09 ; \mathrm{DF}=1 ; \mathrm{P}<0.001$ for linear trend.

$\chi^{2}=3 \cdot 12 ; \mathrm{DF}=2 ;$ no significant deviation from lineari ty.

The men exposed to asbestos did not differ greatly from their controls in smoking history. Nevertheless, it is important to look carefully at the combined effect of the two causal factors. Table II shows that for each of the three smoking groups there were proportionately more exposed men among the patients with carcinoma than among the controls. Using the statistical methods of Woolf, ${ }^{5}$ we found no significant evidence that the relative risk differed between the three smoking groups. Averaged over all smoking groups the :nean relative risk was $2 \cdot 35$. Thus exposure to asbestos of this type more than doubled the risk of cancer. In our sample the relative risks for the three smoking groups $(0-14,15-24$, and 25 or more cigarettes/day) were $1.08,2.92$, and 3.26 respectively. Although these figures were consistent with a constant risk from asbestos exposure (independent of smoking level), they were also consistent with some element of synergism.

If exposure to asbestos increases the risk of bronchial carcinoma, we would expect carcinoma to be present earlier in life in those who were exposed. Table III shows the age distribution of the patients with

TABLE II-Relation between carcinoma and asbestos exposure in men with different smoking habits

\begin{tabular}{|c|c|c|c|c|}
\hline & & Exposed & Not exposed & Total \\
\hline \multicolumn{5}{|c|}{$0-14$ cigarettes/day } \\
\hline $\begin{array}{l}\text { Patients with cancer } \\
\text { Controls.. } \quad . .\end{array}$ & $\begin{array}{l}. \\
\cdots\end{array}$ & $\begin{array}{r}7 \\
12\end{array}$ & $\begin{array}{l}28 \\
52\end{array}$ & $\begin{array}{l}35 \\
64\end{array}$ \\
\hline Relative risk & . & \multicolumn{2}{|c|}{$1 \cdot 08$} & \\
\hline \multicolumn{5}{|c|}{ 15-24 cigarettes/day } \\
\hline $\begin{array}{l}\text { Patients with cancer } \\
\text { Controls.. } \quad . .\end{array}$ & $\begin{array}{l}. . \\
.\end{array}$ & $\begin{array}{l}25 \\
10\end{array}$ & $\begin{array}{l}66 \\
77\end{array}$ & $\begin{array}{l}91 \\
87\end{array}$ \\
\hline Relative risk & . & \multicolumn{2}{|c|}{$2 \cdot 92$} & \\
\hline \multicolumn{5}{|c|}{$\geqslant 25$ cigarettes/day } \\
\hline $\begin{array}{l}\text { Patients with cancer } \\
\text { Controls.. } \quad . .\end{array}$ & $\because$ & $\begin{array}{r}26 \\
7\end{array}$ & $\begin{array}{l}49 \\
43\end{array}$ & $\begin{array}{l}75 \\
50\end{array}$ \\
\hline Relative risk $\quad \ldots$ & $\ldots$ & \multicolumn{2}{|c|}{$3 \cdot 26$} & \\
\hline
\end{tabular}

Weighted result for all smoking categories:

mean relative risk $=2 \cdot 35$ (95\% confidence limits $1 \cdot 39-3 \cdot 97)$ mean relative risk $=2 \cdot 35(95 \%$ confidence limits $1 \cdot 39-3 \cdot 97)$
$\chi^{2}=2 \cdot 89 ; \mathrm{DF}=2$; no significant heterogeneity between smoking groups. 
TABLE III-Age and asbestos exposure in patients with bronchial carcinoma

\begin{tabular}{c|c|c|c}
\hline Age (years) & Exposed & Not exposed & Total \\
\hline $30-49$ & 7 & 11 & 18 \\
$50-59$ & 24 & 38 & 62 \\
$60-69$ & 20 & 71 & 91 \\
70 & 7 & 23 & 30 \\
\hline All ages & 58 & 143 & 201 \\
\hline
\end{tabular}

$\chi^{2}=4.47 ; \mathrm{DF}=1 ; \mathrm{P}<0.05$ for linear trend.

$\chi^{2}=1 \cdot 88 ; \mathrm{DF}=2 ;$ no significant deviations from linearity.

carcinoma divided into those who had been exposed and those who had not. The peak age group for the exposed men was 50-59, compared with a peak age of 60-69 in the unexposed. Further analysis showed that the exposed patients presented on average three years earlier, with a mean age of 59 years, than the unexposed patients, who presented at 62 . This difference was significant.

Table IV considers the operability of the 201 patients and shows that exposure to asbestos did not contribute to the operability of cancer. The carcinoma was inoperable in $60^{\circ}{ }_{0}$ of those who had been exposed to asbestos and $57^{\circ} \circ$ of those who had not.

Tissue was available for histological study in 161 of the 201 patients with cancer and table $\mathrm{V}$ summarises the findings. Anaplastic carcinoma was nearly twice as common among the exposed men as among the unexposed. Nevertheless, this excess would not explain completely the observed association between carcinoma and exposure, which must also increase the risk of squamous cell carcinoma. Table VI shows the results of the asbestos fibre counts on the lungs of 73

TABLE IV-Operability of carcinoma in patients exposed to asbestos

\begin{tabular}{|c|c|c|c|c|}
\hline & & Exposed & Not exposed & Total \\
\hline $\begin{array}{l}\text { Resection ... } \\
\text { Inoperable... }\end{array}$ & $\therefore$ & $\begin{array}{l}23 \\
35\left(60^{\prime \prime}{ }_{0}\right)\end{array}$ & $\begin{array}{l}61 \\
82\left(57{ }^{\prime \prime}\right)\end{array}$ & $\begin{array}{r}84 \\
117\end{array}$ \\
\hline
\end{tabular}

$\chi^{2}=0 \cdot 15 ; \mathrm{DF}=1 ;$ no significant association.

TABLE V-Occupational asbestos exposure and histological findings in 161 patients with cancer from whom specimens were taken

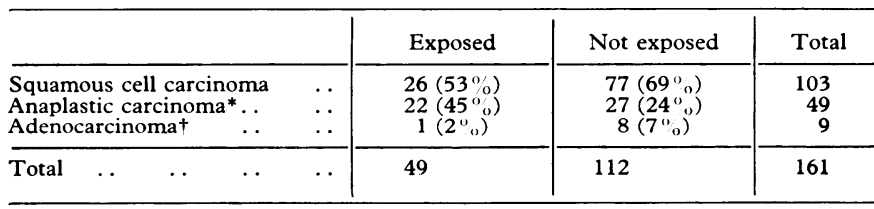

*Including oat-cell and atypical carcinoma.

+ Including alveolar carcinoma.
$x^{2}=7 \cdot 74 ; \mathrm{DF}=2 ; \mathrm{P}<0.05$

TABLE VI-Asbestos fibre counts in lung tissue taken from 73 patients (19 exposed; 54 unexposed to asbestos) undergoing lung resections for carcinoma

\begin{tabular}{|c|c|c|c|c|c|}
\hline & & & No of patients & $\varkappa^{2}(D F=1)$ & $\mathbf{P}$ \\
\hline \multicolumn{6}{|c|}{1000 fibres $/ g$} \\
\hline 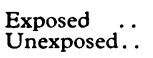 & $\ldots$ & $\ldots \mid$ & $\begin{array}{r}6 \\
28\end{array}$ & $2 \cdot 32$ & $0 \cdot 13$ \\
\hline \multicolumn{6}{|c|}{$>1000$ fibres $/ g$} \\
\hline $\begin{array}{l}\text { Exposed .. } \\
\text { Unexposed.. }\end{array}$ & $\therefore$ & $\therefore \mid$ & $\begin{array}{l}13 \\
26\end{array}$ & $2 \cdot 32$ & $0 \cdot 13$ \\
\hline \multicolumn{6}{|c|}{$>10000$ fibres $/ g$} \\
\hline $\begin{array}{l}\text { Exposed .. } \\
\text { Unexposed.. }\end{array}$ & $\because$. & $\ldots 1$ & $\begin{array}{l}11 \\
16\end{array}$ & $4 \cdot 82$ & 0.03 \\
\hline \multicolumn{6}{|c|}{$>100000$ fibres $/ g$} \\
\hline $\begin{array}{l}\text { Exposed .. } \\
\text { Unexposed. }\end{array}$ & $\begin{array}{l}\cdots \\
\cdots\end{array}$ & $\begin{array}{l}. . \\
\therefore\end{array}$ & $\begin{array}{l}5 \\
0\end{array}$ & & 0.0008 \\
\hline \multicolumn{6}{|c|}{$>150000$ fibres $/ g$} \\
\hline $\begin{array}{l}\text { Exposed .. } \\
\text { Unexposed.. }\end{array}$ & $\therefore$ & $\begin{array}{l}. \\
.1\end{array}$ & $\begin{array}{l}4 \\
0\end{array}$ & & 0.0036 \\
\hline \multicolumn{6}{|c|}{$>200000$ fibres: $g$} \\
\hline$\underset{\text { Unposed }}{\text { Unexposed.. }}$ & $\begin{array}{l}\cdots \\
\cdots\end{array}$ & $\begin{array}{l}. \\
\cdots\end{array}$ & $\begin{array}{l}3 \\
0\end{array}$ & & 0.0156 \\
\hline
\end{tabular}

patients-19 exposed and 54 unexposed-expressed as numbers of fibres per gram of lung tissue. With the technique used even one fibre counted would give a result of over 1000 fibres/g.

We found no evidence of an association between the presence of asbestos fibres and exposure when these very small fibre counts were used as the criterion. When any higher level (from 10000 fibres/g upwards) was taken, however, a statistically significant association was found. As there were very few patients with more than 100000 fibres/g, significance levels for these higher concentrations were calculated by Fisher's exact test, based on the hypergeometric distribution.

\section{Discussion}

The basis of this study was a detailed occupational history of patients with suspected bronchial carcinoma and of matched controls. In this respect the study differs from most others, which have obtained information from selected groups-for example, from asbestos workers-from necropsy studies, or from questionnaires of surviving relatives. We took care to exclude the possibility of asbestosis in the patients with cancer by performing physical and radiological examinations and pulmonary function tests.

Routine hospital case records are inadequate for assessing possible exposure to asbestos, as such terms as "engineer," "fitter," or even "manager" may disguise the fact that the patient is or has been exposed to asbestos. We believe that careful interview of the person concerned is the best method available but are conscious that the technique is open to some objections. It might be argued that in our study the interviewer was biased towards obtaining a history of exposure in those patients whom he knew were being investigated for lung cancer and less concerned when interviewing the control series. It was not possible to arrange for the two groups to be unidentified in this respect, and unconscious bias cannot be excluded. But this likelihood was lessened by interviewing all the men admitted in one year before the diagnosis was confirmed; by the structure of the interviews, which was constant; and by not analysing the results until all interviews were completed. Again, patients admitted to a thoracic surgical centre might have been more concerned about the possibility of exposure to asbestos causing their disability and their memories might therefore have been improved, but the interview structure and the fact that the dangers of asbestos were not so widely appreciated by the public in 1972 both reduce this possibility.

Furthermore, some support for the accuracy of the interviewing technique comes from the fibre counts on the resected lungs (table VI), which tended to show an association between a history of exposure and the finding of fibres, although statistical significance was observed only at a level of 100000 fibres/g -accounting for only about a quarter of the exposed lungs. The relevance of these fibre counts to the presence of the cancer is uncertain and could be assessed only by examining the lung samples of patients without cancer controlled for age, sex, and place of residence, since there is evidence that the latter affects the amounts of asbestos found in lungs. ${ }^{6}$

Our data on the smoking habits of this group of patients are consistent with the well-documented association between cigarette smoking and lung cancer. ${ }^{4}$ The figures further suggest that whatever the number of cigarettes smoked, exposure to asbestos increases the risk of cancer. Selikoff et $a^{7}$ reported a 92-fold increased risk of cancer in asbestos workers who smoked compared with that in non-smokers not working with asbestos. Although our figures are consistent with some element of synergism they do not support synergism of this order but point rather to independent roles of smoking and asbestos.

The characteristic histological cell type of "asbestos cancer" of the lung is regarded by most authorities to be adenocarcinoma, ${ }^{8}$ but, as Whitwell et al pointed out, ${ }^{8}$ the frequency of various histological types will vary depending on whether a series is derived from biopsy, operation, or necropsy. The less operable types of tumour will feature more in a necropsy series and 
Whitwell et al quote a frequency of adenocarcinoma, which often presents with metastases, of $2 \%$ in a biopsy series and of $28 \%$ in a necropsy series. This may partly explain the small numbers of adenocarcinomas in our series, but the numbers were too small for firm conclusions.

Warnock and Churg, ${ }^{9}$ in a necropsy study of lungs, found significantly higher levels of ferruginous bodies in patients with carcinoma and concluded that even extremely low levels of asbestos exposure may have a carcinogenic effect. Their work can be questioned on the basis of a lack of detailed occupational history, but their conclusions agree with ours.

The implementation of the asbestos regulations may have largely eliminated the occupational risk for workers in scheduled industries, ${ }^{11}$ but our findings show that there is a risk for those whose occupation may not be primarily associated with asbestos. It is among these workers, numerically an important group, that asbestos-induced disease will probably be found in the future. The degree and the length of exposure to asbestos that is carcinogenic is something that is not established. Small amounts of asbestos can be found in the lungs at routine necropsies, ${ }^{6}{ }_{11}^{12}$ and it is unlikely that very small amounts of inhaled asbestos increase the risk of cancer. Our figures are consistent with the hypothesis that the risk of cancer is related to dose and duration of exposure and with the possibility that there is a safe lower limit.

The increasing use of asbestos and the comparatively long latent interval between exposure and neoplasia ${ }^{13}{ }^{14}$ suggest that the incidence of "asbestos cancer" will increase. Malignant pleural mesothelioma is now accepted as resulting from comparatively short exposure to comparatively small amounts of asbestos, usually many years before the appearance of the tumour. We must now seek diligently for possible previous exposure to asbestos in all cases of bronchial carcinoma.

We thank the physicians of the general hospitals in Ashington, Bishop Auckland, Chester-le-Street, Durham, Gateshead, Newcastle upon Tyne, and South Shields for allowing us to interview patients under their care and Miss M R Sanderson and Mrs M B Thompson for technical help.

\section{References}

${ }^{1}$ Lynch, K M, and Smith, W A, American fournal of Cancer, 1935, 24, 56

- Berry, G, Newhouse, M L, and Turok, M, Lancet, 1972, 2, 476.

${ }^{3}$ Enterline, $\mathrm{P}$, de Coufle, $\mathrm{P}$, and Henderson · V, British fournal of Industrial Medicine, 1973, 30, 162 .

4 Royal College of Physicians, Smoking and Health Now, London, Pitman Medical, 1971.

${ }^{5}$ Woolf, B, Annals of Human Genetics, 1955, 19, 251.

${ }^{6}$ Doniach, I, Swettenham, K V, and Hathorn, M K S, British fournal of Industrial Medicine, 1975, 32, 16.

' Selikoff, I J, Hammond, E C, and Churg, J, Journal of the American Medical Association, 1968, 204, 106.

* Whitwell, F, Newhouse, M L, and Bennett, D R, British fournal of Industrial Medicine, 1974, 31, 298.

9 Warnock, M L, and Churg, A M, Cancer, 1975, 35, 1236.

${ }^{10} \mathrm{Knox}, \mathrm{J}$ F, et al, British fournal of Industrial Medicine, 1968, 25, 293.

${ }^{11}$ Cauna, D, Totten, R S, and Gross, P, fournal of the American Medical Association, 1965, 192, 371

${ }^{12}$ Ashcroft, T, British Medical fournal, 1968, 1, 614.

${ }^{13}$ O'Donnell, W M, Mann, R H, and Grosh, J L, Cancer, 1966, 19, 1143.

${ }^{14}$ Selikoff, I J, et al, American fournal of Medicine, 1967, 42, 487.

(Accepted 10 fanuary 1977)

\title{
Maintenance digoxin after an episode of heart failure : placebo-controlled trial in outpatients
}

\author{
SYLVIA M DOBBS, W I KENYON, R J DOBBS
}

British Medical fournal, 1977, 1, 749-752

\section{Summary}

The need for maintenance digoxin treatment was assessed in a double-blind, variable-dose, crossover comparison with placebo. Forty-six outpatients who had been prescribed the drug for heart failure were studied; 33 were in sinus rhythm and the remainder in atrial fibrillation. Mean serum digoxin concentrations in those with sinus rhythm averaged $1.33 \mathrm{nmol} / \mathrm{l}$, but a lower concentration, averaging $0.97 \mathrm{nmol} / 1$, was accepted in those with atrial fibrillation as six of them developed bradycardia. Sixteen of the 46 patients deteriorated on placebo, and eight completely recovered when digoxin

\footnotetext{
Department of Pharmacology, Materia Medica and Therapeutics, University of Manchester, Manchester M13 9PT

SYLVIA M DOBBS, MB, MSC, honorary research fellow at Tameside General Hospital (Present address: Department of Pharmacology and Therapeutics, Middlesex Hospital Medical School, London).

Tameside General Hospital, Ashton-under-Lyne, Lancashire W I KENYON, FRCP, consultant physician

University College Hospital Medical School, London R J DOBBS, DCH, MRCP, research fellow
}

was reintroduced; in the remainder additional diuretics were required temporarily. Spirometric values deteriorated on changing to placebo whether or not the patient showed clinical evidence of recurrence of heart failure.

In a separate study of nine patients who showed no clinical evidence of deterioration on placebo, reintroduction of digoxin caused a shortening of left ventricular ejection time, which persisted for at least a month. This suggests that the inotropic response to digoxin is sustained during maintenance treatment.

\section{Introduction}

Traditionally, once a patient has been digitalised for heart failure treatment is continued indefinitely. There is, however, a substantial risk of toxicity should renal function deteriorate ${ }^{1}$ or the severity of the heart disease increase. ${ }^{2-4}$ It is therefore important to determine whether patients benefit from such treatment.

Rogen $^{5}$ found that withdrawal of digoxin resulted in decompensation and tachycardia in over three-quarters of a group of patients in atrial fibrillation with a history of cardiac failure. In contrast Dall ${ }^{6}$ found that the drug could be withdrawn in almost three-quarters of a group in sinus rhythm, although many had no known cardiac lesion. We assessed the need for continuous treatment in clinically stable outpatients, who were either in sinus rhythm or in atrial fibrillation with no history of 